indecisiveness of the lower federal courts on the question..$^{83}$ After a declaration of war a fair test of constitutionality may be politically impossible. It is therefore important that Congress draft an act with some safeguards, because they may be the only safeguards.

To place much faith in legal tests of constitutionality of any war legislation is improvident at any time and surely a delusion after war has been declared. But the term, "reasonable," will allow the judiciary a check if that resource becomes politically advisable. Under the same political circumstances Congress too has a check, for Congress still holds the purse strings. It cannot appropriate money for war purposes for more than two years at a time. ${ }^{84}$ The May Bill contains provision for taxation ${ }^{85}$ but not for appropriation. This powerful democratic weapon in the hands of parliamentary bodies, even as a check upon the war power of the executive, should not be overlooked. Lincoln did appropriate money without the assent of Congress, but Congress nevertheless ratified his use of Treasury funds. ${ }^{86}$ Congress probably could appropriate a large sum contingent upon declaration of war. ${ }^{87}$ But aside from the uselessness of so doing, Congress should retain its power to appropriate and to cut off appropriations as a fundamental check upon the war power of the President.

\title{
PAROL EVIDENCE AND THE BONA FIDE PURCHASER
}

No aspect of the law has presented more confusion than the parol evidence rule as applied to the interpretation of written instruments. The prevailing common law rule, which is still followed in many jurisdictions, is the so-called "clear meaning" rule, which permits parol evidence to explain the terms of the written instrument only where the terms are ambiguous. ${ }^{\mathrm{I}}$ In contrast, the "liberal" rule permits evidence to explain the intended meaning of the words of the instrument even where the words are unambiguous as used in their ordinary

${ }^{83}$ See Fosgate Co. v. Kirkland, I9 F. Supp. I52 (S.D. Fla., I937). Cf. S.E.C. v. Electric Bond \& Share Co., 18 F. Supp. I3 I (S.D.N.Y., 1937); Boggus Motor Co. v. Onderdonk, 9 F. Supp. $95 \circ$ (S.D. Tex., 1935). As to contesting tax statutes, see amendment, 49 Stat. Io27 (I935); Beeland Wholesale Co. v. Davis, 88 F. (2nd) 447 (C.C.A. 5th I937).

Perhaps it is not preposterous to assert that the chief of staff of the army, or the chairman of the committee on military affairs could bring a mandamus against the Secretary of Treasury to compel him to submit to Congress a plan of war taxation in accordance with a requirement like Section Ir of the May Bill (note 9 supra). This controversy passes the area of the moot case and the advisory opinion. $36 \mathrm{Col}$. L. Rev. Ir69 (1936). It will lead to a decision which will prevent parties from acting or refusing to act at their peril. 49 Harv. L. Rev. I35I (1936). It will be difficult to confine the decision to the narrow mandamus issue; the purpose of the taxation requirement will be in question, and the answer will involve the validity of the entire bill.

\footnotetext{
84 Const., art. I, § 8, cl. I2. $85 \&$ II.

${ }^{86}$ Berdahl, War Powers of the Executive in the United States Iro-III (1920).

${ }^{87}$ See United States v. Butler, 297 U.S. I (I935).

${ }_{5} 5$ Wigmore, Evidence $\$ 246$ I (2d ed. I923).
} 
sense. ${ }^{2}$ The liberal rule has recently secured widespread support. ${ }^{3}$ It here is purposed to examine these conflicting rules in the light of the general parol evidence rule and to suggest a qualification to the liberal rule in the case of a bona fide purchaser who has relied upon the clear meaning of the language employed in the written instrument.

The process of interpretation involves two closely associated steps. First, a meaning must be attached to the words used; and secondly, this meaning must be fitted to external facts and things. ${ }^{4}$ The clear meaning and liberal rules are concerned primarily with the first process. They determine what evidence may be considered in the search for the meaning intended to be expressed by the words of the instrument. The second process of interpretation does not involve the clear meaning or liberal rules, for if the meaning attached does not fit external facts and things a "latent" ambiguity results, and it is well settled that parol evidence may then be admitted. ${ }^{5}$

A comparison of the clear meaning and liberal rules necessarily involves a consideration of the reasons underlying the general parol evidence rule. These generally are said to be the policies in favor of fraud prevention and certainty in the terms of the transaction. ${ }^{6}$ Yet one may well question whether the dangers envisaged by the parol evidence rule are equally present in the interpretation situation, where the evidence is offered merely to explain the intended meaning of the words, and in the ordinary situation, where additional or wholly different terms are sought to be shown by parol evidence. In the former case the dangers of fraud and uncertainty are necessarily limited since the party seeking to establish a peculiar meaning is limited to an explanation of the words employed in the writing. Moreover, a further guaranty against fraud and uncertainty is provided where the liberal rule is adopted, by creating a presumption in favor of the normal meaning of the words.?

One reason frequently given for retaining the clear meaning rule is that it is necessary in order to reserve the construction of written instruments to the judge. ${ }^{8}$ Briefly, the rationale is that a consideration of extrinsic evidence would

$=$ Ibid.

${ }^{3}$ See notes 15 and 16 infra.

4 Malaguti v. Rosen, 262 Mass. 555, I6o N.E. 532 (1928).

$s$ Circa 1597 Sir Francis Bacon, Maxims Rule 27 (Work's Spedding's ed. 196r vol. XIV, p. 273): "'Patent' is that which appears to be ambiguous upon the deed or instrument; 'latent' is that which seemeth certain and without ambiguity for anything that appeareth upon the deed or instrument, but there is some collateral matter that breedeth the ambiguity. 'Ambiguitas patents' is never holpen by averment, and the reason is, because the law will not couple and mingle matter of specialty, which is of higher account, with matter of averment-But if, it be 'ambiguitas latents,' then otherwise it is." Several American cases are Cole v. Clark, 3 Wis. 292 (I854); Hall v. Bartlett, I58 Cal. 638, I12 Pac. I76 (I9I0). See also Brown v. Quintard, 177 N.Y. 75,69 N.E. 225 (I903).

${ }^{6}$ Urquico, Parol Evidence Rule, 5 Notre Dame Lawyer 303 (1930).

7 See note 27 infra. A presumption would seem to be a sufficient protection, especially if it establishes the burden of persuasion.

${ }^{8}$ See note I supra. 
raise questions of fact concerning the intention of the parties, which necessarily must be decided by the jury. This argument is less impressive, however, when it is remembered that even under the clear meaning rule similar questions of fact must now be determined by the judge in cases of ambiguity. Moreover, the solution by the jury of questions of fact regarding the construction of writings is not guaranteed by the Constitution, since this was never a common law function of the jury.

The usual reason given for adherence to the clear meaning rule is that no evidence off the face of the instrument will be admitted to vary or contradict the terms of the written instrument.9 This statement is more a conclusion than a reason. The fallacy of such a broad generalization is obvious, since the only things on the face of the instrument are physical marks, which are intended to express a meaning. These marks require an interpretation. ${ }^{10}$ In order to attach any meaning whatsoever to the symbol employed, the minimum evidence of ordinary, normal usage must be considered even though the court will take judicial notice of this usage. In order to show the meaning actually intended by the party or parties, perhaps further evidence of a local or individual usage of the words must be considered. Thus the problem is what types of evidence may be used to show the meaning for which the particular symbol is to stand.

The general types of parol evidence of usage have been classified as follows: ${ }^{1 I}$ (I) General Usage-the normal meaning attached to the term by people generally; (2) Local Usage-a particular meaning attached to the term by people of the locality or class of the writer; (3) Individual Usage-the individual meaning attached to the term by the party or parties or by a very small group to which they belong.12 In terms of the above classification the clear meaning rule declares simply that after the court has considered parol evidence of a general, or possibly, a local standard of usage and a plain meaning appears, which is applicable to external things and facts, no evidence of an individual usage will be admitted. The liberal rule, on the other hand, declares that evidence of every type is ${ }^{13}$ admissible in order to determine the meaning ascribed to the words by the immediate parties or the writer.

9 Firestone Tire and Rubber Co. v. Werner, 204 Wis. 306, 236 N.W. I 8 (I93I).

${ }^{\text {so } 5}$ Wigmore, op. cit. supra note $\mathrm{I}, \S 2462$.

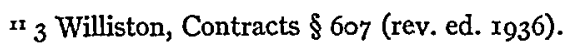

${ }^{22}$ In applying the standard a further qualification is necessary in the case of bilateral agreements in order to conform to the objective theory of contracts, namely, that where a peculiar individual usage was intended the party employing this peculiar usage must reasonably have supposed that his peculiar meaning was understood by the other party to the instrument. See 3 Williston, op. cit. supra note $12, \S 603$. Wigmore embodies this qualification in a separate standard, calling it the mutual standard of interpretation. 5 Wigmore, op. cit. supra note $x, \S 2460$.

${ }^{23}$ This rule is frequently stated to include any evidence except the direct statement of the parties on the theory that the admission of such evidence would bring into competition the conveyor's informal statement and his formal statement. It would constitute too great a 
One may well wonder why the courts have been so hesitant in approving the liberal rule. The following suggestion is offered as a possible explanation. Since the judge ordinarily will take judicial notice of the normal meaning, while evidence of an individual usage must be offered in open court, the interpretationsituation appears to be practically identical with the ordinary situation where evidence is offered to vary or contradict the written instrument. The courts have identified the written instrument with the normal meaning of the language employed in the instrument, while in reality the latter is merely evidence of the meaning intended to be expressed. Evidence of an individual usage is offered to explain and not to contradict the written instrument. It only contradicts or rebuts the evidence of normal usage on the issue of what was actually intended by the words.

In effect the courts are saying that the statute, which requires some transactions to be in writing in order to be legally operative, further requires that the words of the writing must be used in their normal sense. Granting that some resort to extrinsic evidence is absolutely necessary, the courts in following the clear meaning are declaring an arbitrary rule that extrinsic evidence, other than that necessary to determine the normal meaning, will not be admitted, to vary or contradict the normal meaning regardless of its probative force. This is a rule of substantive law. ${ }^{\mathbf{1 4}}$

Generally rules of substantive law are desirable in so far as they give effect to important policy considerations in a given situation. But here the nominal policy justifications for such a rule, namely, fraud prevention and certainty, are clearly overbalanced in the ordinary case by the desirability of enforcing the intention of the writer or the parties. This policy is expressed in the principle of "freedom of contract," which means that individuals are allowed to create those legal relations which they desire and intend. Any restriction upon the intentions of the party or parties must be justified by some policy stronger than that which is expressed in the principle of "freedom of contract." Thus, the liberal rule has been enthusiastically supported by Professor Wigmore ${ }^{\mathrm{Is}}$ and given a sweeping indorsement in the Restatement of Property. ${ }^{16}$ Where a third

departure from the accepted policies embodied in the Statute of Wills, Statute of Frauds and parol evidence rule. Rest., Property $\S 242$, comment j (Tent. Draft No. 7, 1937). In re Smith's Will, 254 N.Y. 283, I72 N.E. 499 (1930); Leland v. Hoke, 28I N.Y. Supp. 9I9 (Sup. Ct. I935). The evidence is not offered to change or add new terms to the instrument, but merely to explain those used in it. Thus, there would seem to be little reason for drawing a distinction in this case, since the ordinary policy considerations behind these rules are not of controlling importance in the interpretation situation.

${ }^{14}$ Chadburn and McCormick, Parol Evidence Rule in North Carolina, 9 N.C. L. Rev. I5I (I93I); 5 Wigmore, op. cit. supra note $\mathrm{I}, \S 2400$.

${ }^{25} 5$ Wigmore, op. cit. supra note Io: "The truth is that whatever virtue and strength lies in the argument for the antique rule leads not to a fixed rule of law, but only to a general maxim of prudent discretion."

${ }^{16}$ Rest., Property $\$ 242$, comment d and i (Tent. Draft No. 7 I937). 
party is concerned, however, additional policies in favor of safety and security in commercial transactions arise. Thus a rule of substantive law, which excludes evidence offered to vary the clear and normal meaning of the words in a written instrument, may well be justified where a bona fide purchaser has relied upon the normal meaning.

Whether or not the proposed distinction should be recognized turns upon the question of how far the expectations and interests of a bona fide purchaser should be protected. Ordinarily this protection is accorded by a flat rule of substantive law, i.e., the equity rule that a sale to a bona-fide purchaser will cut off hidden equities. Here the device employed to protect the bona fide purchaser is an application of the parol evidence rule, but this is little different from affording him protection by a flat rule of law.

Whatever the explanation for the harsh treatment of the bona fide purchase at early law may be, it is certain that with the changes in social organization the emphasis has shifted from protection of property interests toward considerations of commercial expediency as controlling factors in the law. Thus doctrines of implied authority and estoppel, the recording acts, the Torrens System, and title insurance have been developed to protect the innocent buyer and encourage commercial transactions.

The same considerations of commercial expediency for the easy, secure transferability of property would seem to operate, possibly in a less urgent way, in the situation considered in this note. In the case of conveyances of land it seems an unduly harsh treatment of the bona fide purchaser, who has purchased in reliance upon the clear meaning of the words of the recorded instrument, to be defeated, many years after the execution of the instrument, by parol evidence of an individual usage which he could not possibly discover by searching the record. In so far as this result is allowed the purpose of the recording acts is defeated. In declaring an inclusive clear meaning rule the courts have emphasized the intolerable hardship that would result to successors in title if parol evidence of an individual usage were to be admitted.

On the other hand we are not working too great a hardship on the party seeking to establish an individual meaning, if the clear meaning rule is applied in the case of the bona fide purchaser. In the land conveyance situation he would almost never be a bona fide purchaser, since he would be charged with knowledge of the clear meaning of the recorded instrument and ordinarily he would be put on notice by possession of the holder under the clear meaning. If an heir or donee is seeking to set up an individual meaning, there is little hardship, since he has never enjoyed possession and has not parted with value.

\section{II}

To what extent have the courts been influenced by these considerations? It must be admitted that neither the courts nor the writers, with the possible ex- 
ception of Professor Williston, ${ }^{17}$ recognize the suggested qualification explicitly. With the hope of determining whether this qualification is implicit in the decisions but unexpressed in the opinions, an analysis has been made of the decisions of five states, New York, California, Illinois, Massachusetts, and Wisconsin. Since the land conveyance situation presents the most convincing arguments for the adoption of the suggested qualification, the case-study has been limited largely to cases of deeds, wills and leases. The interpretation problems are, however, the same in other cases where written instruments are required, and in so far as the policies for protection of the bona fide purchaser are important, the qualification should be applied in the interpretation of other types of written instruments.

A case-study is complicated for several reasons. First, the line between the clear meaning and liberal rules is only superficially clear, for it is evident that the courts may declare any language to be ambiguous and so give "lip service" to the clear meaning rule while actually making a radical departure from the traditional standard. Secondly, in attempting to appraise the cases on their facts, an accurate study is difficult, since there is no standard by which the degree of ambiguity may be measured in the particular case. The dictionary is not adequate because of the many alternative meanings given for even the most common words. Furthermore a senterice or phrase is frequently involved.

In view of the handicaps attending an accurate case-analysis the results of this case-study are offered hesitantly.

r. As between immediate parties, the cases are in confusion in the application of the clear meaning or liberal rules, although there is a marked tendency in the United States toward a relaxation of the traditional "clear meaning" rule.

In New York the prevailing tendency is an adherence to the clear meaning rule. $^{18}$ Dwight v. Fancher, ${ }^{19}$ is a modern case supporting this view. The court refused to admit evidence offered by the attorney who drew the will that the testator intended to include the grandchildren of H.D. in a devise to the "children of my cousin, H.D." In recent times this rule has been qualified by a tendency to say that surrounding circumstances may be shown to put the court in the position of the writer. ${ }^{20}$ The distinction between "surrounding circum-

${ }^{17} 3$ Williston, op. cit. sitpra note $\mathrm{II}, \S 608$. Williston tacitly approves this distinction when he suggests that evidence of local usage should be admissible as between immediate parties, but not as between parties who have relied upon the normal meaning of the instrument in the case of wills and deeds.

${ }^{28}$ See 37 Col. L. Rev. 842,847 , note 28 (r937); Dwight v. Fancher, 245 N.Y. 7 I, 156 N.E. I86 (r927), reaffirmed in Dwight v. Dwight, 262 N.Y. 284 , 186 N.E. 787 (1933); Brown v. Quintard, I77 N.Y. 75, 69 N.E. 225 (1903); Matter of Wells, x $x_{3}$ N.Y. 396, 2 I N.E. $x_{37}$ (I889); Mann v. Mann, I4 Johns. (N.Y.) I (I8I6).

${ }^{29} 245$ N.Y. 7r, I56 N.E. I86 (I927), reaffirmed in Dwight v. Dwight, 262 N.Y. 284, I86 N.E. 787 (1933).

${ }^{20}$ In Matter of Dialogue, I59 Misc. 18, 287 N.Y. Supp. 237, 240 (1936) the court declared the following formula: "The court must first ascertain from the language employed in the 
stances" and parol evidence is not apparent; nor is it made clear why an individual word-usage by the testator is not one of those "surrounding circumstances." Moreover, the courts are prone to qualify the rule further by declaring words, ordinarily well-understood, to be ambiguous. ${ }^{2 x}$ Armstrong v. Sheldon ${ }^{22}$ illustrates this process. The court declared the words "to my heirs in portions according to the laws and statutes of the state of New York, the same as if I died intestate" to be so ambiguous as to justify the admission of a memorandum naming persons the testator believed to be his heirs, for the purpose of ascertaining the testator's intention. Many cases go to the full extent of holding the surrounding circumstances to be always admissible. ${ }^{23}$ The leading case for this view is In re Smith's Will. . $^{24}$ Evidence of the state of the testatrix's property and the terms of a former will were offered on the question of whether the clause of a latter will, executed in Florida ("hereby revoking all former wills by me made"), revoked a prior New York will. The court admitted the evidence in holding that the Florida will did not affect the New York will. It declared: "It is the modern rule that, 'with the exception of direct statements of intention, no extrinsic fact relevant to any legitimate question arising in the interpretation of writings and admissible under the general rules of evidence' will be shut out."

California has attempted to codify the liberal rule of interpretation. ${ }^{25}$ In spite of an apparently clear statutory adoption of the liberal rule the courts have adhered tenaciously to the clear meaning rule in the majority of the cases. ${ }^{26}$ Indeed the courts have gone even further. Since one sentence of the California Code of Civil Procedure" states, "but this section does not exclude other evi-

will, when read in the light of circumstances surrounding the testator at the time of its execution, what disposition of property the testator intended to make." Pozzemini v. Brooks, II8 Misc. 79x, x94 N.Y. Supp. 748 (1922); Lewis v. Palmer, r67 N.Y. Supp. 1053 (Sup. Ct. I9I7); Potter v. Pike, 183 N.Y. Supp. 842 (Sup. Ct. I920).

${ }^{2 x}$ Matter of Phipps, 2I4 N.Y. 378, IO8 N.E. 554 (IgI5); Ryerss v. Wheeler, 22 Wend. (N.Y.) 148 ( 1839 ).

${ }^{22} 43$ App. Div. 248, 60 N.Y. Supp. I (I89g).

${ }_{23}$ In re Smith's Will, 254 N.Y. 283 , I72 N.E. 499 (1930); Dobbins v. Pratt Chuck Co., 242 N.Y. I06, I5 I N.E. 146 (1924); Matter of Neil, 238 N.Y. 138, I44 N.E. 48I (1924); In re Patterson's Estate, I39 Misc. 872, 249 N.Y. Supp. 44I (I93I); In re Shumway's Will, ${ }_{3} 8$ Misc. 429,246 N.Y. Supp. 178 (I930).

24254 N.Y. $283, x 72$ N.E. 499 (r930).

${ }^{25}$ Deering's Cal. Code of Civ. Proc. $x_{93} \mathrm{x}, \S \mathrm{r} 86 \mathrm{r}$ : "The terms of a writing are presumed to be used in their primary and general conception, but evidence is nevertheless admissible that they have a local, technical or otherwise peculiar signification, and were so used and understood in the particular instance, in which case the agreement must be construed accordingly."

${ }^{26}$ See 7 Calif. L. Rev. 4I7 (I9I9) and 37 Col. L. Rev. 842, 843, note 6 (I937). Holcomb Estate Co. v. Burke, 4 Cal. (2d) 289, 48 P. (2d) 669 (I935); Symonds v. Sherman, 2I9 Cal. 249, 26 P. (2d) 293 (1933); Estate of Kelleher, 202 Cal. I24, 259 Pac. 437 (r927); Higgins v. California P. \& A. Co., rog Cal. 304, 4I Pac. ro87 (r895).

${ }^{27}$ Deering's Cal. Code of Civ. Proc. I931, \$1856. 
dence ... . to explain an extrinsic ambiguity," the courts have imported Lord Bacon's obsolescent distinctions into the law. ${ }^{28}$ It has even been stated to be settled that parol evidence ordinarily is not admissible to cure a patent ambiguity..$^{29}$ This cannot be said to be the present rule, ${ }^{30}$ however, and a very few cases have apparently adopted the liberal rule. ${ }^{3 \mathrm{x}}$

Concerning Illinois little more can be said than that the cases are in confusion,,$^{32}$ although the majority seems to apply the clear meaning rule. The Tllinois formula for interpretation is ( $\mathrm{I}$ ) the cardinal rule of construction is to ascertain the testator's intention, ${ }^{33}$ (2) the intention is found by construing the words employed by the testator in the light of his circumstances and surroundings, ${ }^{34}$ and (3) where the clear meaning rule is applied, the courts add the qualification that the instrument is the only criterion of the intention of the parties, if there is no ambiguity in the terms used. ${ }^{35}$ Three cases illustrate the prevalent confusion in Illinois. In Abrahams v. Sanders ${ }^{36}$ the court failed to declare the words ambiguous but held that evidence of surrounding circumstances was admissible to show what was intended by the words "die without definite issue." Later in the same year the court apparently adopted the clear meaning rule in Nice $v$. Nice, ${ }^{37}$ holding that extrinsic evidence was not admissible to explain the instrument where property was to be divided equally between parties named "making them all my equal heirs." Two years thereafter in Walker v. Walker ${ }^{8}$ the Illinois court strongly supported the liberal rule in holding that evidence of surroundings and circumstances at the time of executing the will was admissible to show what was intended by the word "heirs."

In this respect Massachusetts and Wisconsin may be treated together. Both consistently adhere to the clear meaning rule. The Massachusetts rule is fre-

${ }^{28}$ See note 5 supra.

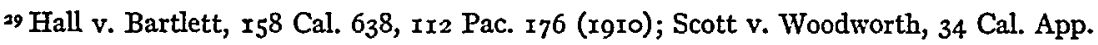
400, I67 Pac. 543 (I9I 7 ). See 7 Calif. L. Rev. 417, 43r, note 65 (I9I9).

30 Prible v. Abrahams, 88 Cal. 245, 26 Pac. 99 (I89r). See 7 Calif. L. Rev. 4rg, 43r (rgrg).

${ }^{31}$ In Higgins v. Calif. Petroleum Co., I20 Cal. 629, 52 Pac. I080 (r898) the court held that parol evidence was admissible to show what was intended by the term "gross ton," thereby reversing an earlier holding on this same term. Higgins v. Calif. P. \& A. Co., rog Cal. 304, 4I Pac. 1087 (r895).

${ }^{32}$ See 37 Col. L. Rev. 842,847 , note 28 (r937). For cases applying the clear meaning

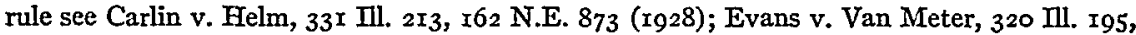
150 N.E. 693 (I926); McCormick v. Sanford, 318 III. 544, I49 N.E. 476 (I925); Crabtree v. Dwyer, 257 Ill. Ior, roo N.E. 5 ro (IgI2). For a selection of cases applying the liberal rule see La Rocque v. Martin, 344 Ill. 522, I 76 N.E. 734 (r93 I); Boys v. Boys, 328 Ill. 47, I59 N.E. 217 (r927); Himmel v. Himmel, 294 III. 557, I28 N.E. 64I (1920); Hadden v. Shoutz, I5 III. $58 \mathrm{I}(\mathrm{r} 854)$.

33 Dahmer v. Wensler, 350 Ill. 23 , 182 N.E. 799 (1932).

${ }_{34}$ Strickland v. Strickland, 27 I Ill. 6I4, $\operatorname{xII~N.E.~} 592$ (IgI6).

35 Crabtree v. Dwyer, 257 Ill. ror, xoo N.E. 5 Io (IgI2).

${ }^{36} 274$ Ill. 452, x 33 N.E. 737 (x916).

37275 Ill. 397, Ir 4 N.E. r40 (I9r6).

${ }^{38} 283$ Ill. II, II8 N.E. xor4 (I9I8). 
quently expressed as follows: If the language is ambiguous or capable of a double interpretation, parol evidence of the attendant circumstances, the situation of the parties and the purpose of the conveyance is admissible to ascertain the intent of the parties in their use of words. ${ }^{39}$ One contract case, Nelson v. Hamlin,,$^{40}$ has been discovered which seems to encroach on this rule by readily finding an ambiguity. The words "it being understood that you wish me to stay in my present position with the Phillips Co. pending the working out of your present dealings, or until conditions make it necessary to place me elsewhere" were held to be not so clear and definite as to exclude evidence of previous conversations between the parties.

In Wisconsin it is deemed "well settled that where a term in the written instrument is ambiguous, it is proper to receive evidence to ascertain the sense in which the parties intended to use the term. ${ }^{45}$ The problem is rather how far the courts will expand upon this rule by declaring ordinary words to be ambiguous. In Jackson Milling Co. v. Chandos ${ }^{42}$ evidence of circumstances surrounding the execution of the grant was admitted to explain the terms " 2000 inches of water" under an eleven foot head. In other cases the courts have declared "vicinity" 43 and a provision to "clear" land 44 to be ambiguous and have admitted extrinsic evidence to explain them.

2. As between a bona fide purchaser and one seeking to establish a peculiar individual meaning, no case has been discovered, with the possible exception of an analogous situation in Patch $v$. White, 45 in which the liberal rule has been applied explicitly, although in a few cases the court has gone a long way in declaring an ambiguity.

As a judicial confirmation of the proposed qualification to the liberal rule, this result is evidence of a negative character. Even so this negative finding strongly tends to support the suggested distinction in those states where the liberal rule has secured a widespread, if not exclusive adoption.

In New York no cases in which a bona fide purchaser is concerned have adopted the liberal rule expressly. ${ }^{6}$ The cases admitting parol evidence against

${ }^{39}$ Snider v. Deban, 249 Mass. 59, I44 N.E. 69 (I924); Dean v. Eldridge, 217 Mass. 583, I05 N.E. 449 (rgr4).

${ }^{40} 258$ Mass. 33 I, 155 N.E. I8 (r927).

${ }_{4} \mathrm{~F}$ Firestone Tire and Rubber Co. v. Werner, 204 Wis. 306,236 N.W. I 18 (I93I).

${ }^{42} 82$ Wis. 437,52 N.W. 759 (I892).

43 Burton v. Douglass, I4I Wis. Iro, I23 N.W. 63 I (rgog).

44 Zielica v. Wozalla, 162 Wis. 603 , 156 N.W. 623 (Igr6).

45 II7 U.S. 2 Io ( 1886 ). In this case the majority allowed parol evidence to show a mistake fifty years after the transaction in question, and, after striking out the mistake, filled the gap created by the introduction of extrinsic evidence. This case is not strictly analogous since it involves a mistake. The arguments, however, pressed by the dissent are a strong judicial expression of the policies underlying the distinction under consideration.

${ }_{46}^{6}$ Cordua v. Guggenheim, 274 N.Y. 51, 8 N.E. (2d) 274 (1937); Leland v. Hoke, 28x N.Y. Supp. 9 Ig (Sup. Ct. I935); Wright v. Wright, xr8 N.Y. Supp. 994 (Sup. Ct. rgog); Van Nostrand v. Moore, 52 N.Y. I2 ( 8873 ). 
the bona fide purchaser are all explained on the ground that an ambiguity is present. Several cases, however, stretch the traditional clear meaning rule by declaring ordinary words to be ambiguous. ${ }^{47}$ For example in Livingston v. Ten Broeck $4^{8}$ where the deed reserved a right to cut wood for buildings, and wood for a fence was cut, the court held the word "buildings" to be equivocal and admitted evidence of later usage by the parties. In Kitching v. Browon $n^{49}$ evidence was held to be admissible to show that "tenement house" in a restrictive covenant was not intended to include a high class apartment house.

In California where the liberal rule is infrequently applied, the adherence to the clear meaning rule is unanimous if a bona fide purchaser is concerned..$^{\circ}$ In Stanley ข. Green"s the words "more or less one mile square of land in the place known as 'Rincon de los Cameros' commencing on the wagon road and ending at the point of the hill at the east" were held to be so ambiguous that evidence of grantor having pointed out the land was admissible. It is only surprising that the California court, which occasionally applies Lord Bacon's maxims regarding patent ambiguities, did not declare the deed void for uncertainty.

In Illinois the third party cases follow the clear meaning rule generally..$^{52}$

- In Dick v. Goldberg ${ }^{53}$ evidence of the advertisements and oral statements of the original parties was held inadmissible to explain a building restriction, which precluded the erection of "any building known as a flat or tenement building, hereby covenanting to erect thereon only a single private dwelling house, (excepting the stable as aforesaid) for a period of 20 years." The appellants contended that the twenty-year period was an affirmative covenant which only affected the latter part of the phrase. Two third party cases apparently adopt the liberal rule as expressed in Hadden v. Shoutz.54 However, these cases may be distinguished on their facts. In Piper v. Connelly 55 the contract prior to the deed was admitted to explain what boundary was intended by "west along south bank." Here, however, there was a plat on the back of the deed which the court considered to be incorporated into the deed. It apparently conveyed the title to the middle of the river. In the face of this inconsistency extrinsic evidence

${ }^{47}$ Kitching v. Brown, 180 N.Y. 4 I4, 73 N.E. $24 x$ (1905); Lytle v. Beveridge, 58 N.Y. 592 (1874); Livingston v. Ten Broeck, I6 Johns. (N.Y.) I4 (I8rg); Watson v. City of New York, 67 App. Div. 573, 73 N.Y. Supp. I027 (rgo2).

$4^{8} 16$ Johns. (N.Y.) 14 (18Ig).

49 I80 N.Y. $4 \times 4,73$ N.E. 24 I (I905).

${ }^{50}$ Dent v. Bird, 67 Cal. 652 (1885); Stanley v. Green, 12 Cal. 148 (1859); Anderson v. Palladine, 39 Cal. App. 256, r28 Pac. 553 (1918).

${ }^{5 x}$ I2 Cal. ${ }_{4} 8$ (1859).

s2 Wise v. Wouters, 288 II. 29, I23 N.E. 35 (I9r9); Roberts v. Dazey, 284 Ill. 24I, II9 N.E. 9 Io (IgI8); Coogan v. Jones, 278 III. 279, II 5 N.E. 877 (I9I7); Mason v. Merrill, I29 IIl. 503, 2 I N.E. 799 (1889).

53295 Ill. 86, 128 N.E. 723 (I920).

54 I5 Ill. 58I (1854). This was an early leading case for the liberal view.

55 ro8 กl. 646 (1884). 
would be admitted under the clear meaning rule. The second case, Kuecken v. Voltz ${ }^{56}$ held the deeds of adjoining land admissible to show whether an easement "appurtenant" or "in gross" (personal to grantor) had been retained by the words "excepting and reserving therefrom to feet across the west end of said premises for an alley." Here the court might well have declared an ambiguity in this respect.

Since the Massachusetts courts apply the clear meaning rule where immediate parties are concerned, it is small confirmation of the suggested qualification that they also affirm the clear meaning rule where a bona fide purchaser is involved. ${ }^{57}$ The strongest support for the proposed distinction in Massachusetts comes by way of a dictum. In Bennett v. Newell, $5^{8}$ a bona fide purchaser was one of the parties. The court held that evidence of a conversation between the original parties was not admissible to explain the words of a deed granting an easement so long as a certain building "stands and remains substantially in its present condition," saying, "Owners subsequent to them [original parties] can be affected only by the language of the deed."

The Wisconsin courts apply the same rule in a suit between immediate parties and in one in which a bona fide purchaser is interested. The clear meaning rule is applied, ${ }^{59}$ but it is expanded by declaring words ordinarily wellunderstood, to be ambiguous. Where a bona fide purchaser is a party Pritchard v. Lewis ${ }^{60}$ illustrates this process. Evidence of the parties' later usage under the deed was admitted to explain whether "excepting and reserving" certain land referred to a fee or merely a right of way. The court declared "sufficient ambiguity existed to warrant the admission of the testimony offered."

One English case has been discovered in which the dangers sought to be evaded by the suggested qualification have gained judicial recognition. While declaring a flat clear meaning rule in all cases, Tindal, C.J. in Attorney-General v. Shore 6r $^{\mathrm{x}}$ said: "If it were otherwise, no lawyer would be safe in advising upon the construction of a written instrument, nor any party, in taking under it; for the ablest advice might be controlled and the clearest title undermined, if, at some future period, parol evidence of the particular meaning which the party affixed to his words .... might be set up to contradict or vary the plain language of the instrument itself." It is noteworthy that the argument for the safety and security of conveyances is the sole reason given for the

${ }^{56}$ IIO Ill. 264 (I884).

57 Hirsch v. Fischer, 278 Mass. 492, I80 N.E. 230 (1932); Albiani v. United Artist's Corp., 269 Mass. 544, I69 N.E. 435 (1930); N.X. Central Ry. Co. v. Central New England Ry. Co., 264 Mass. I28, I62 N.E. 324 (r928); White v. Shippee, 216 Mass. 23, ro2 N.E. 948 (1913).

${ }^{58} 266$ Mass. 227 , I65 N.E. 27 (I929).

${ }^{59}$ Owens v. Hughes, $\mathrm{x} 88$ Wis. $2 \times 5$, 205 N.W. $8 \mathrm{r} 2$ ( 1925$)$; Barnhardt v. Stern, $\mathrm{x} 82$ Wis. I97, I96 N.W. 245 ( $\mathrm{rg}^{23}$ ); In re Barkhausen, I42 Wis. 292, I24 N.W. 649 (Igro); Messer v. Oestreich, 52 Wis. 684, Io N.W. 6 (I88r).

${ }^{60}$ I25 Wis. 604, I04 N.W. 989 (x905). 6r Ir Sim. 592, 63I (I843). 
clear meaning rule by Tindal, C.J. This argument is sound. It is believed, however that the clear meaning rule should be restricted to the situation in which a bona fide purchaser's interests have intervened where these policies are actually operative.

As previously pointed out, the suggested qualification contemplates protection of the bona fide purchaser by a restriction on the types of parol evidence which will be admitted to explain the instrument. Three rather limited situations have been discovered in which the bona fide purchaser has been afforded protection explicitly through this device. In the law of bills and notes a small minority view admits parol evidence to show an individual usage of the words of indorsement, where the immediate parties are concerned, ${ }^{62}$ but holds that such evidence is inadmissible after negotiation to a holder in due course. ${ }^{63}$ Likewise where the question is whether the signing of a note was intended to be made in an individual capacity or as an agent, many states declare that extrinsic evidence may be admitted, when the controversy is one between the original parties to the paper, but not when the paper is in the hands of a holder in due course. ${ }^{64}$ Under the doctrine of equitable mortgages parol evidence may be admitted to show that a deed absolute on its face was intended as a mortgage in a suit between the original parties, but it is inadmissible where the interests of a bona fide purchaser have intervened..$^{6}$ "This latter situation is not strictly analogous to that under consideration since it is not properly a problem of interpretation. There are no words to interpret. Nevertheless it neatly illustrates the method of protecting the bona fide purchaser by restricting the admissibility of parol evidence.

By way of summary it has been suggested that in the interpretation of wills, deeds, and leases all types of parol evidence should be admitted as between the immediate parties to the written instrument. Where a bona fide purchaser's interests have intervened, parol evidence of the individual usage of the writer or the original parties should be excluded. Evidence of general usage clearly is admissible. Although the admission of evidence of local usage is a debatable question, it probably should be admitted on the theory that the bona fide purchaser is chargeable with knowledge of this usage.

62 Parol evidence is held admissible as between the immediate parties, to show the actual contract assumed by the regular indorser of a bill or note upon transferring the same with the intent to pass property therein to the indorsee, without reference to indorsement being in full or in blank in the following jurisdictions: Maine, Nebraska, Iowa, North Carolina and Ohio. See 4 A.L.R. 764,768 ( $\mathrm{rg}$ I9).

${ }^{6} 3$ Holmes v. First Nat'l Bank, 38 Neb. 326,56 N.W. Iorr (I893); True v. Bullard, 45 Neb. 409,63 N.W. 824 (I895); Hill v. Shields, 8 I N.C. 250 (I879); Skinner v. Church, 36 Iowa 91 (I872).

${ }^{6}$ I Mechem, Agency § II62 (2d ed. x9r4).

${ }_{65}$ Walsh, Treatise on Mortgages $\S 7$ ( $x_{934}$ ed.); Wilson, The Parol Evidence Rule in Nebraska, 4 Neb. L. Bul. II5, x52 ff. (I925); Names v. Names, 48 Neb. 70I, 67 N.W. 75 I (1896). 
The conclusion which is to be drawn regarding the suggested qualification of the liberal rule is that the writers, with the possible exception of Professor Williston, have not recognized the distinction, that in a few limited situations protection has been afforded to the bona fide purchaser by restricting the admissibility of parol evidence of an individual usage, but that the decisions do not recognize this qualification expressly. On the basis of the cases it is believed, however, that this qualification may be made since no cases have been found in which the liberal rule has been expressly applied in the case of a bona fide purchaser, while the liberal view has been followed frequently in suits between the immediate parties. It is urged further that the suggested qualification will assume an increasing importance if the liberal rule secures a more universal adoption.

\section{A DEFENSE OF NON-MANAGING DIRECTORS}

Outstanding among present day examples of the lag in legal rules behind changing commercial practices is the case presented by non-managing/corporate directors. ${ }^{x}$ The rapidity with which business practices are altered, especially the recent changes in the make-up of corporate boards, intensifies the conflict between law and practice. Non-managing directors, a result of the vast dimensions to which corporations have grown, have individually different and more or less limited functions and competencies. They are usually supposed to take little or no part in the general management of their corporations. The law, however, still sees but one type of director-one entrusted with active and constant supervision of all corporate officers and affairs, ${ }^{2}$ and whose duty is sanctioned by strong and absolute civil and penal liabilities. ${ }^{3}$ Courts and authors alike have refused to recognize the existence of, or at least a justification for, non-managing directors. ${ }^{4} \mathrm{~A}$ single standard of diligence and liability is imposed upon all. 5 Thus a non-managing director is considered not as a

I The distinction between non-managing and executive or managing directors has been clearly defined in Samuel, Shareholders' Money, Append. I, \$24(I) (I933).

a People v. Central Fish Co., II7 App. Div. 77, 79, Ior N.Y. Supp. Iro8, Irog (I907); Hun v. Cary, 82 N.Y. 65, 74 (1880); Dwight, Liability of Corporate Directors, I7 Yale L.J. 33, 36 (1907); Ballantine, Corporations 359 (1927); Samuel, op. cit. sulpra note I, at I4r. See also note 5 infra.

3 People v. Mancuso, 255 N.Y. 463, 469, I75 N.E. 177 , I78 (193 I); Wormser, Directors -Figures of Earth, I Brooklyn L. Rev. 28, 30, 35 (I932); Wormser, Frankenstein, Inc. I34 (I93x). See New York Penal Law I909, $\$ \$ 667$ (3)(d), 397 (for bankers specifically); California Penal Code $1872, \S \S 568,572$. See also note 5 infra.

4 People v. Mancuso, 255 N.Y. 463, 469; 775 N.E. I77, 178 (r93r); Douglas, Directors Who Do Not Direct, 47 Harv. L. Rev. 1305 (1934); Wormser, Directors-Figures of Earth, I Brooklyn L. Rev. 28, 35 (1932); Wormser, Frankenstein, Inc. I28 (I93I); Dwight, op. cit. supra note 2 , at 35 .

5 Briggs v. Spaulding, I4I U.S. I32, 447 (I820); Bowerman v. Hamner, 250 U.S. 504, 5 I3 (I9r8); Allen v. Roydhouse, 232 Fed. roro, Ior4 (D.C. Pa. I9r6); Morawetz, Corporations 